\title{
VILLA-LOBOS: O SELVAGEM DA MODERNIDADE
}

\author{
Arnaldo D. Contier \\ Dept ${ }^{\circ}$ de História - FFLCH/USP
}

\begin{abstract}
RESUMO: Estudo sobre as conexōes entre a música de Villa-Lobos e os diferentes discursos culturais das elites brasileiras. $O$ consumo da música em vários momentos históricos, a relação entre o público ouvinte e a criaçāo artística são analisados com vistas a apontar os vínculos entre música / compositor; músico / mecenas; músico / Estado e discursos e projetos políticos.

ABSTRACT: This is a study of the connections between the music of Villa-Lobos and the different cultural discourses of the Brazilian elites. The consumption of music in various historical moments, the relations betwcen listening public and artistic creation are analyzed with the intention of pointing out the ties between music/composer; musician/macenas; musician/State and discourses and political projects.
\end{abstract}

PALȦRAS-CHAVE: O nacional-popular na música, propaganda Cultural, Modernismo, Elite, Gosto musical.

KEYWORDS: The national-popular in music, cultural propaganda, Modernism, elite, musical taste

\section{Introdução}

No Antigo Regime, o compositor-artesâo escrevia músicas profanas (óperas, sinfonias, sonatas) ou

"Nunca na minha vida procurei a cultura, a erudiçảo, o saber e mesmo a sabedoria nos livros, nas doutrinas, nas teorias, nas formas ortodoxas. Nunca, porque o ineu livro era o Brasil. Năo o mapa do Brasil nix minha frente. mas a terra do Brasil, onde eu piso, onde eu sinto, onde eu ando, onde eu percorro. Cada hoinem que eu encontro no Brasil representa uma forma estética na concepção musical."

(Heitor Villa-Lobos, Joảo Pessoa. 195I) religiosas (cantatas, oratórios, réquiens) para atender encomendas de príncipes, arquiduques, arcebispos, visando o entretenimento da aristocracia. $O$ artista - homem pobre, em sua maioria - exercia função semelhante aos serviçais de um palácio ou de uma abadia: "... os músicos eram tāo indispensáveis nestes grandes palácios quanto os pasteleiros, os cozinheiros e os criados, e normalmente tinham o mesmo status na hierarquia da corte. (...) a maior parte dos músicos, sem dúvida, ficava satisfeita quando tinha garantida a subsistência, como as outras pessoas de classe média na corte..." (ELIAS, 1995, p. 18). 
O público ou a elite cortesã na França de Luís XIV, como na Lisboa de Pombal, ditava normas ético-estéticas, impedindo, em geral, uma possível autonomia do artista para exercer um cargo vitaltcio, ou não, no sentido de escrever músicas por conta própria. Excepcionalmente, alguns compositoresartesãos conseguiram rebelar-se, não se submetendo às ordens de seus mecenas. A Arte da Fuga, escrita por Johann Sebastian Bach em 1750-1, por exemplo, pode ser considerada como uma utopia face à demanda social de sua época, sem nenhuma vinculação contratual ' . O autor do Cravo bem-temperado, durante toda a sua vida, sofreu um forte controle ou uma censura permanente dos agentes da nobreza ou da Igreja Luterana, em especial, após a sua chegada a Leipzig, em 1727.

O impacto ideológico do gosto musical dominante na nobreza do século XVIII repercutiu, inclusive, nos domínios mais restritos da linguagem e do estilo do compositor. A verdade musical era representada pelo sistema tonal, baseado no movimento cadencial, “...definida uma área tonal (dada por uma nota tônica, que se impōe sobre as demais notas da escala, polarizando-as), levanta-se a negação da dominante, abrindo a contradição que o discurso tratará de resolver $\mathrm{cm}$ seu desenvolvimento. Mas a grande novidade que a tonalidade traz ao movimento de tensão e repouso e a trama cerrada que ela the empresta, envolvendo nele todos os sons da escala numa rede de acordes, isto é, de encadcamentos harmônicos" (WISNIK, 1989, p. 106). Essas leis gramaticais, internalizadas nas escutas das elites cor-

1. Composiçāo didática baseada na matemática musical. A Arte da Fuga é um resumo de todas as possibilidades da escrita fugada. Conjunto de uma série de variaçōes contrapontísticas estruturada a partir de um terna central em ré menor. tesãs, eram obedecidas pela maioria dos compositores-artesãos do Antigo Regime.

Consolidou-se, durante o século XIX, um novo tipo de auditório: o teatro burguês. Esse novo público comprava ingresso para assistir a um determinado espetáculo operístico ou de música para concerto. Por essa razão, esse novo decodificador das mensagens clássico-românticas precisava ser seduzido ou conquistado pelos compositores a cada apresentação de suas respectivas peças musicais. Em oposição ao artista-artesão do Antigo Regime, o compositor, no âmbito de novos contextos sócio-culturais, tornouse mais livre e autônomo face às cxigências dos empresários de teatros de Milāo, Roma, Nápoles, Viena, Berlim, Londres, Paris. Em contrapartida, o cromatismo sediado no âmbito do sistema tonal foi sendo ampliado por alguns compositores da segunda metade do século XIX. Assim, multiplicaram-se as "... altcraçōes de acorde por deslizamento de semitom", possibilitando o afloramento de "diversas modalidades de acordes de sétima, e o acorde de nona de dominante passa a ser tomado como ponto de referência analítico (...) o jogo de alterações desenvolverá uma harmonia cada vez mais cromática e um sistema de modulaçōes cada vez mais distantes e rápidas" (WISNIK, 1989, p. 131). A tensāo entre a crise (dissonância) e o repouso (consonância) atingiu o mercado capitalista. Dc um lado, compositores que se ajustaram a um determinado imaginário musical das elites: “... Offenbach e Napoleão III foram feitos um para o outro. Assim como o Império de Napoleão era c não era uma fantasia de opereta, assim também as operetas de Offenbach eram e não eram um comentário satírico sobre o governo impcrial (...) Orfeu levou Paris inteira a dançar" (FRIEDRICH, 1993, p. 119); e, de outro, artistas mais ousados, como Richard Wagner, que utilizou no Prelúdio do $1^{\circ}$ ato de Tristāo e Isolda uma modulaçāo contínua, preconizando a dissolução do sistema tonal, tendo recebido críticas ácidas por oca- 
sião da apresentação de Lohengrin em Paris, "... para marcar sua presença musical em Paris, Wagner decidiu reger três concertos de suas obras, com trechos de Tannhäuser e Lohengrin e as aberturas de $O$ navio fantasma e Tristão. Parecia não levar em conta que teria de pagar todas as despesas e que os três concertos acrescentariam mais $1 !$ mil francos a suas dívidas. Com igual displicência, não enviou convites à imprensa, que reagiu à altura. 'Cinqüenta anos dessa música, e a música estará morta', declarou o crítico do Ménestrel, 'pois a melodia terá sido assassinada, e a melodia é a alma da música'. 'Se essa é a música verdadeira, prefiro a falsa', declarou outro crítico" (FRIEDRICH, 1993, p. 130).

Em resposta às críticas recebidas em Paris, Richard Wagner teceu uma série de considerações sobre a tirania do mercado, que inibia uma possível autonomia do artista numa sociedade burguesa e capitalista: “... mas qual é o caráter das instituiçōes teatrais que hoje em dia têm capacidade para albergar o conjunto das diferentes artes? São meras empresas industriais, mesmo nos casos em que são largamente subvencionadas pelos Estados ou pelos príncipes. Quase sempre acontece que a respectiva direção é entregue aos mesmos indivíduos que ontem estavam a frente de um qualquer empreendimento especulativo ligado aos cereais e que amanhã hão de aplicar os seus grandes conhecimentos no negócio do açúcar, isto se não tiverem sido iniciados na compreensão da dignidade do teatro por entre os mistérios da camarária ou de funções similares. Enquanto um teatro for considerado apenas como um meio de aplicação de dinheiro capaz de proporcionar lucros ao capital investido, o que aliás concorda , com o caráter dominante da nossa sociedade (...) E é também por isto mesmo que não pode deixar de saltar aos olhos de qualquer pessoa inteligente o fato de ser radicalmente necessário libertar o teatro de toda a submissão à especulação industrial..." (WAGNER, 1990, p. 102-3).
No Brasil, durante a segunda metade do século XIX, graças à importação de pianos da Europa pelas elites agrárias e urbanas, intensificou-se o consumo de partituras de músicas clássicas, ligeiras ou populares (polcas, mazurcas, valsas, modinhas) ${ }^{2}$. Paralelamente, muitos professores italianos, franceses, alemães imigraram para o Rio de Janeiro, São Paulo, Minas Gerais, onde lecionaram piano, canto, flauta, violino para as filhas de fazendeiros de Itu, Campinas, Sorocaba, Vassouras, ou de comerciantes e burocratas paulistanos e cariocas. Os saraus tornaramse atividades cotidianas das elites dominantes do $\mathrm{II}^{\circ}$ Reinado e da República ${ }^{3}$. “... até o final do século $\mathrm{XIX}$, a rua apresentava para a família tradicional uma forte ameaça ao seu equilíbrio, capaz de corromper seus valores morais e desintegrar sua solidez como instituição (...). A implementação de projeto civilizador chega ao ápice na reforma Passos, regenerando esteticamente o espaço urbano, controlando a questão sanitária (...) a nova aparência física da cidade, a ampliação dos meios de transporte e comunicação e a multiplicidade de atividades de diversão levam modelos de família a utilizarem intensamente o espaço urbano (...) era durante as temporadas líricas que as famílias da elite carioca mais freqüentavam a noi-

2. DEVRIÈS-LESURE, Annik. "Le Commerce de L'Édition Musicale Française au XIXème Siècle”. Revista Música, 6 (1/2), 1995, p. 3-43.

3. “... são incontáveis os cursos de música, de solfejo, de dança. A paixäo pela música desperta o tino comercial de firmas estrangeiras, como a Gautret Ainé, casa de Paris, com instrumentos de música (...) Noutro anúncio ensina-se a 'coser, marcar, bordar a ouro, froco, matiz, missanga e de várias qualidades, desenhar em vidro, papel e cetim, a tintas e crayon, bordar sobre cera e vidro. ler, escrever gramaticalmente, piano, canto e francês...". RENAULT, Delso. Rio de Janeirs: a vida refletida nos jornais (1850-1870). Rio de Janeiro, Civilização Brasileira, 1978, p. 190-212. 
te. Sua presença é mais rara nos espetáculos populares" (ARAÚJO, 1993, p. 283-5; 345).

Em oposição à criação de um ínfimo mercado consumidor de literatura pclas elites, inexistiu no Brasil um mercado capaz de consumir obras de compositores eruditos brasileiros. Mesmo os artistas sintonizados com o imaginário romântico curopeu, como, por exemplo, Antônio Carlos Gomes (18361896), não conseguiram sobreviver financeiramente, sem a ajuda oficial do mecenas D. Pedro II ${ }^{4}$.

Para ser aceito pelas elites republicanas, VillaLobos travou uma verdadeira cruzada em prol da nacionalizą̧ão do gosto musical: "... o que posso afirmar é que muito me esforcei para encontrar uma 'maneira bem brasiliense', pelo que tenho passado, sofrido, observado e aprendido por mim mesmo. A minha intenção foi que essa 'maneira' se transformasse numa espécie de farol invisível para iluminar o caminho por mim desbravado aos jovens artistas que viessem depois. Para amoldar a sincretização a um sabor nacional, utilizei-me de elementos das mais estranhas manifestaçōes da natureza, quer através do homem primitivo ou civilizado, quer dos seres musicais, colhidos ao acaso" s. Para penetrar a complexa teia de representações político-culturais da sociedade urbana brasileira nas primeiras décadas do século

4. Antônio Carlos Gomes (1836-1896). Estudou trisingulo, clarineta, violino $\mathrm{c}$ piano. Tocou $\mathrm{e}$ cantou modinhas eun saraus promovidos pelos fazendeiros de llu e Campinas. Em Săo Paulo aperfeiçoou seus estudos de violino com o professor francês Paul Julien, tendo se apresentado em audições particulares e num pequeno teatro localizado no Pátio do Colégio. Nesta fase, como seresteiro, escreveu a modinha Quem sabe (1860). No

- Rio de Janeiro matriculou-se no Conservatório de Música, tendo escrito sob encomenda do diretor - Francisco Manuel da Silva - uma Cantata, que foi executada na presença de D. Pedro II (1I março 1860). Graças ao sucesso de suas óperas $A$ Noire do Castelo (1863) e Joana de Flandres (1863). Carlos Gomes ob-
$X X$, Villa-Lobos transfigurava-se ora num menestrelperegrino na busca da alma brasileira em suas andanças pelo interior do Brasil; ora num artesāo da modernidade, aceitando convites e apoios de mecenas burgueses, a fim de divulgar suas músicas para as elites; ora num funcionário público, para desenvolver projetos pedagógicos em prol da alfabetização musical de um novo público: o povo brasileiro; ora num profissional voltado para as exigências da indústria cultural, escrevendo a opereta Magdalena, uma aven. tura musical para a Broadway ou a trilha sonora para o filme Green Mansions ( $A$ Flor que nâo morreu), produzido pela Metro Goldwyn Mayer.

1. O compositor-peregrino e a descoberta do povo (1905-22) (Rio de Janeiro, Salvador, Recife, Belém, Manaus)

De 1905 a 1913, Villa-Lobos realizou diversas viagens pelo Brasil, percorrendo capitais (Vitória, Salvador, Recife, Fortaleza, Belém), fazendas, vilas, povoados. Nestas andanças, dialogou com os contadores de causos (homens pobres) e ouviu centenas de pregōes, aboios, desafios, cocos.

Na sua primeira viagem $-1905-$. Villa-Lobos, sem recursos financeiros, vendeu o restante dos livros

teve uma pensão do governo imperial a fim de prosseguir seus estudos cm Milão, com o professor Lauro Rossi. Na Itália, escreveu diversas operas, que foram apresentadas nos principais teatros da Europa. Com o advento da República (1889), a sus pensão foi suspensa pelo novo govemo, obrigando-o a retomar ao Brasil. Em 1895, Carlos Gomes, já doente, foi convidado pelo governador do Pará para assumir a direção do Conservatório Musical de Belém, cuja posse ocorreu em $1^{\circ}$ de junho de 1896. Três meses após a șua nomeação para dirigir esse Conservatório, Carlos Gomes faleceu...

5. Presença de Villa-Lobos. Rio de Janeiro, MEC/DAC-Museu Villa-Lobos, (5), 1970. 
herdados de seu pai (pequeno burguês, funcionário da Biblioteca Nacional) para custear as peregrinações pelos Estados do Espírito Santo, Bahia, Pernambuco. Nos anos posteriores, em suas novas andanças em busca da alma musical da Nação, o compositor ora integrava pequenas orquestras de companhias regionais de operetas; ora apresentava-se em cabarés, teatros de revista ou dancings. Em Fortaleza (1910), conheceu Donizetti - excelente músico e boêmio inveterado - que tocava piano e saxofone para acompanhar revistas e operetas. Villa-Lobos, em companhia de Donizetii, resolveu prosseguir viagem até Manaus: "... a história dessa viagem tem algo de homérico (ou de rabelaisiano): aqui e ali, Villa deve carregar Donizetti, embriagado, de cidade para cidade. Tocam em toda a parte, ouvem mais ainda, naufragam duas vezes em canoa, tomam quinino para resistir à malária. No Amazonas, Villa passa a namorar uma inglesa, e vai com ela até a ilha de Barbados, centro do jogo. Perdem dinheiro, obviamente, e acabam tocando em bares e cabarés para pagar o hotel, ela no piano, ele no violoncelo. Mas foj em Barbados que ele começou a escrever as Danças caracteristicas africanas..." (HORTA, 1987, p. 20-1).

Num intervalo dessas viagens, Villa-Lobos matriculou-se no Instituto Nacional de Música do Rio de Janeiro para estudar Harmonia com Frederico Nascimento (1907). A sua rebeldia calcada na internalização de novos timbres, ritmos, inspirados nas falas dos artesãos do mundo rural e urbano (chorōes), levou-o a abandonar, em seis meses, esse curso baseado no tradicionalismo - sistema tonal europeu.

$O$ autodidatismo de Villa-Lobos pode ser explicado $\mathrm{em}$ função de sua hostitidade em face de todo sistema cultural sacralizado pelas elites da Belle Époque e de conhecimentos adquiridos, assistematicamente, no ambiente familiar ou através de estudos de partituras de Richard Wagner, Gioacchino Puccini ou do Tratado de Composição de Vincent D'Indy: " ... com cinco anos de idade - 1892 - ini- ciei, num pequeno violoncelo, a vida musical pelas māos de meu pai, que, além de ser um homem de aprimorada cultura geral e excepcionalmente inteligente, era um músico prático, técnico e perfeito (...) aos 10 anos era obrigado por ele, a discernir o gênero, estilo, caráter e origem das obras musicais que me fazia ouvir. Obrigava-me a declarar, com presteza, o nome da nota dos sons ou ruidos que surgiam incidentalmente no momento, como, por exemplo, o guincho da roda de um bonde, ou um pio de um pássaro, ou a queda ocasional de um objeto de metal. Isto tudo com um rigor e energia de severidade absoluta. Ai de mim, se não acertasse..." 6 .

A partir de seu casamento com a pianista Lucília Guimarães, fixou-se na cidade do Rio de Janeiro (1913), indo morar com a família de sua esposa, à Rua Dídimo. Sem emprego fixo, Villa-Lobos apresentava suas obras em recitais e saraus promovidos pelos seus amigos, ou tocava violoncelo na Confeitaria Colombo, durante o dia, e no Assírio (restaurante do Teatro Municipal), à noite. Tentou ministrar aulas particulares de música, tendo conseguido somente um aluno...

Nos fins dos anos 10 e inícios dos 20, Villa-Lobos procurou conciliar suas escutas oriundas de culturas e estratos sociais contrastantes: de um lado, convivia com Anacleto de Medeiros, Pixinguinha, Kalut, Ernesto Nazareth, Catulo da Paixāo Cearense, respirando o clima popular do teatro de revista, dos ajuntamentos de chorões? ${ }^{7}$ e, de outro, no cinema

6. Manuscrito no 78-17A-2E. Rio de Janeiro, Livro do Tombo. Museu Villa-Lobos.

7. "... foi nesta quadra primorosa que imperava o choro nas festus de Santo Antônio, São Joảo, Sĩo Pedro e Sant'Ana. Nos aniverśríos, nos batisados, nos casamentos, os grandes chorōes eran procurados em pontos certos, no Catete, no botequim da Cacela, no Matadouro, no Estácio de Sá, na Confeitaria Bandeira, no Andarai, no Gato Preto e no Botequim Braço de Ouro, no 
Odeon, entrava em contato com o pianista erudito Arthur Rubinstein ou com Darius Milhaud (1917), compositor ligado ao Grupo dos Seis.

Envolvido pela intensa circulaçāo de sons eruditos e populares, Villa-Lobos construiu um imaginário baseando-se nos ideais de coletividade, povo, Nação, Civilizaçāo, progresso, trabalho e disciplina.

Neste momento, a obra villalobiana ora representava traços do romantismo e do simbolismo europeus, aproximando-se de facções do público burguês; ora internalizava antropofagicamente repetições, variações muito comuns na cultura popular, colocando em xeque o gosto dominante. Entre vaias e aplausos, Villa-Lobos procurou modificar o gosto das elites e do povo, almejando criar um mercado de consumo voltado para a música erudita nacionalista e modernista brasileira.

A busca do popular e do nacional na música prendeu-se a uma nova tendência estético-política das vanguardas modernistas na Europa e no Brasil. A internalização de ritmos sincopados ou de novos timbres, como nos Choros n"I para violão (1920), exemplifica, de um lado, o popular como fonte de inspiração do autor erudito, $e$, de outro, o nacional como a representação do retrato do Brasil.

Paradoxalmente, os ritmos sincopados foram decodificados pelas elites como a representação de um povo infantil (negros e ex-escravos) e o violão como o símbolo da malandragem, do 6́cio e da vagabundagem..."

Engenho Velho, no Botequim do Major Ávila, no Portāo VermeIho, no centro da Cidade, Confeitaria do Velho Chico....". Cfr. PINTO, Alexandre Gonçalves. $O$ Choro. Rio de Janeiro, FUNARTE, 1978, p. 95.

8. "... Com efeito, as reformas de Rodrigues Alves, em sua condenaçăo explícita da aparência e da cultura urbanas associadas as tradiçōes tidas como atrasadas, bárbaras e coloniais, desti-
Nesta teia de contradiçōes sócio-culturais, VillaLobos ora era visto como um bom selvagem pelos intelectuais modernistas; ora como um indio antropófago, capaz de jantar as operetas de Johann Strauss ou as mazurcas de Frédéric Chopin pelas elites herdeiras das culturas oficiais da Belle Époque.

$E$, no âmbito desses conflitos, procurou seduzir os coros dos contrários: "... quem nasceu no Brasil e formou sua consciência no âmago deste país, não pode, mesmo que queira, imitar os cantos e os destinos de outros países, embora a sua cultura básica seja transportada do estrangeiro (...) considero a arte uma segunda religião" ".

Envolvido pelas músicas populares, folclóricas, sertanejas, ligeiras e eruditas, Villa-Lobos privilegiou a Arte Culta como o símbolo do progresso, da

navam-se a apoiar a reivindicação de um status 'europeu' - Civilização -, em parte por meio de ataques explícitos a um Brasil antigo, singular (...) Pereira Passos não condenava apenas as ruas estreitas $e$ imundas, mas também as fachadas sem pintura, os estilos rurais de consumo e os aspectos 'búbaros' do Carnaval. Queın sabe o último aspecto seja, afinal, o mais revelador; com seus entrudos e cordőes, o Carnaval expressava em parte uma cultura afro-brasileira da qual a elite afinada com os padrões europeus se envergonhava." NEEDELL. Jeffrey D. Belle Époque Tropical. Sociedade e cultura de elite no Rio de Janeiro na virada do século. São Paulo, Companhia das Letras, 1993, p. 72, 71.

A representą̧̃o do violão como símbolo de culura inferior foi muito muito bem descrita por Lima Barteto no seu romance Trisse Fin de Policarpo Quaresma: "... além do compadre e da filha, as únicas pessoas que o visitavam até então, nos últimos dias, sera visto entrar em sua casa, três vezes por semana e em dias certos, um senhor baixo, magro, pálido, com um violão agasalhado numa bolsa de camurça. Logo pela primeira vez o caso intrigou a vizinhança. Um violão em casa țo respeitável! Que seria?". BARRETO, Lima. Triste Fim de Policarpo Quaresma. São Puulo, Abril Cultural, 1984, p. 12.

9. Manuscrito n"78-17A-2E. Rio de Janeiro, Livro do Tombo, Museu Villa-Lobos. 
civilizaçāo: “... é preciso năo esquecer que a música representa duas finalidades distintas, que só definem os povos cultos e progressistas: - a música popular, popularizada ou popularesca; - a música artística, cientifica (folclore), erudita, transcendente, sacra. O supremo ideal é compreendê-las e amálas, colocando cada qual no seu devido lugar" ".

Imbuîdo de ideais messiânicos, religiosos e nacionalistas, Villa-Lobos nunca criticou, com virulência, o mercado e o gosto dominante como entraves que impedissem a plena divulgação de suas músicas. $\mathrm{Na}$ realidade, questionava a falta de tradição artística do povo ou artistas isolados (compositores, interpretes), que se deixavam seduzir pelos modismos, contribuindo para a formação de um "gosto duvidoso" e prejudicial em face do ideal modernista no campo artístico: “... nenhum povo pode viver sem música, pela simples razão de que a expressão artística é de natureza vital para o progresso intelectual de um povo (...) ... naturalmente, há na música sctorcs espúrios, indivíduos que usam da música nảo para a valorizaçāo, mas sim para detrimento de seus concidadãos. O mercantilismo atinge também as artes, $\mathrm{c}$ quando a música se subordina à ambição, deixa de desempenhar sua funçāo orientadora na opiniāo pública. Sāo os falsos músicos os responsáveis pelo êxodo do povo dos salöes de concerto. $O$ verdadeiro artista, e artista com A maiúsculo, de média cultura geral, ou muita erudição, ou possuidor de vários diplomas é sempre predestinado, e quando em contato com seus semelhantes, necessariamente os empolga. $O$ falso artista, porém, deixa de provocar no coração a emoção que a música sugere, fazendo com que o povo procure outras diversōes, dedique-se a divertimentos de segunda categoria, ao carnaval, ao futebol etc." ".

10. Manuscrito no 74-18A-2E. Rio de Janeiro, Livro do Tombo, Museu Villa-Lobos.

II. Jdem.
Em 1922, já havia internalizado em algumas de suas obras os traços essenciais do modernismo. Por esse motivo, Villa-Lobos foi convidado por Graça Aranha a fim de se apresentar no Teatro Municipal de São Paulo, durante a realização da Semana de Arte Moderna, nos dias 13, 15 e 17 de fevereiro. Trouxe do Rio de Janeiro artistas eruditos já identificados com os traços modernos de sua linguagem (politonalidade; clusters; novas colorações timbrísticas), tais como: Alfredo Gomes, Paulina d'Ambrosio, Frutuoso Viana, Lucília Guimarães, Orlando Frederico, Antāo Soares, Pedro Vieira, Frederico Nascimento Filho. Foram tocadas vinte obras de Villa-Lobos durante a Semana. Todas escritas no período de 1914 a $1921 \ldots$ Ou seja, o único compositor brasileiro convidado para esse Festival, não escreveu nenhuma obra, sob encomenda, para a ocasião. O repertório villalobiano harmonizava-se, em linhas gerais, com as tendências do gosto dominante: traços clássico-românticos e simbolistas. Somente algumas combinações rítmicas ou melodicas, inseridas nos trechos de algumas peças, causaram um certo desconforto nos ouvintes ainda não acostumados com os ruídos da modernidade. As vaias de facçōes do público presente no Municipal, provocadas pela apresentaçāo de uma peça de Erik Satie durante a conferência de Graça Arantha sobre "A emoção estética da arte moderna", proferida na abertura da Semana - 13 de fevereiro -, ou de alguns blocos sonoros escritos por VillaLobos, foram propositalmente exageradas nos depoimentos do autor dos Choros - momentos posteriores a csse Evento -, como uma espécie de marketing pessoal. As vaias das elites sempre foram satirizadas com humor pelo Índio de Casaca: " ... o público levantou-se indignado. Protestou, blasfemou, vomitou, gemeu e caiu silencioso. Quando chegou a vez da música, as piadas das galerias foram tāo interessantes que quase tive certeza de a minha obra atingir um ideal, tais foram as vaias que cobriram os louros (...)"; no terceiro concerto, “... de quando 
em quando, um espectador musicista assobiava o principal tema, paralelamente com o instrumento que desenhava. A Lucília e a Paulina queriam parar, eu me ria e o Gomes bufava, mas foi até o fim..." '2.

Dos seis compositores apresentados na Semana, cinco eram franceses e um brasileiro... E, paradoxalmente, as peças de Villa-Lobos denotavam um forte diálogo com os artistas da França, tão amada pelas elites dominantes da Belle Époque carioca: "... uma atmosfera francesa, com efeito está presente em todo o momento no jovem Villa-Lobos. Ainda em 1918, quando já escrevera o Amazonas e o Uirapuru, a primeira Prole do Bebê para piano, caminha à vontade nos climas e na técnica do impressionismo" (HORTA, 1987, p. 32). Inclusive, muitas das obras de Villa-Lobos possuíam títulos em francês: Lune d'octobre; Jouis sans rétard, car vite s'écoule la vie (poesia de Ronald de Carvalho ou as Historietas apresentadas na Semana).

2. $O$ bom selvagem na capital da modernidade: Paris (1924; 1926-1930)

Em 1922, Villa-Lobos havia completado 35 anos. Autodidata, escreveu mais de uma centena de obras, algumas altamente significativas sob o ponto de vista estético, como, por exemplo, o ballet Uirapuru (1917). Graças à apologia e endeusamento de sua figura como símbolo do retrato sonoro do Brasil Novo pelos intelectuais modernistas, tais como Mário de Andrade, Graça-Aranha, Ronald de Carvalho, Renato Almeida, Oswald de Andrade, Plínio Salgado, Sćrgio Milliet, Villa-Lobos conseguiu apoio financeiro da Câmara dos Deputados e de mecenas burgueses

12. VILLA-LOBOS, H. Jornal do Brasil. Rio de Janeiro, 6 set. 1967.
- Olivia Guedes Penteado, Arnaldo Guinle - a fim de viajar para a França (Paris), em 1924. O objetivo fundamental dessa viagem incidia na divulgação $e$ propaganda a ser realizada na Europa da obra villalobiana, vista pela intelectualidade como a representação da alma brasileira moderna... Numa segunda viagem a Paris, em 1926, Carlos Guinle emprestouthe o seu apartamento mobiliado (Place Saint Michel, $n^{\circ}$ 11) e concedeu-lhe uma pensão mensal.

Em Paris, Villa-Lobos ora peregrinava pela Europa visando a divulgar o imaginário modernista Londres, Amsterdam, Viena, Berlim, Bruxelas, Madri, Lisboa, Liège, Lyon, Amiens, Poitiers -, ora revisava partituras para a Casa Max Eschwig. Nesta fase parisiense, graças à identidade de sua proposta modernista-nacionalista com alguns artistas europeus, o seu círculo de amizades ampliou-se significativamente: Marguerite Long, Izidor Philip, Maurice Risk, René Dumesnil, Magda Tagliaferro, Leopold Stokowsky, Elsie Houston, Edgard Varèse, Arthur Honegger.

Graças aos auxílios financeiros concedidos pelos mecenas brasileiros simpatizantes do modernismo musical, Villa-Lobos, em seu período parisiense, escreveu obras fundamentais, como o Noneto; Rudopoema (dedicada a Arthur Rubinstcin, um grande divulgador das obras pianísticas villalobiana na Europa e nos Estados Unidos); Os Choros n" 2 (para flauta e clarineta em Lá, dedicada a Mário de Andrade), entre outras. Entretanto, continuou enfrentando, na Europa, hostilidades de facçōes do público acostumadas com a tradição: “...Na primeira viagem (1924) ... o público reagiu mal a um tipo de música demasiado ousado para a época, mas Villa-Lobos com isso atraiu a atenção de Jean Wiener, que o contratou para uma série de concertos da música de vanguarda, ao lado de outros músicos que se celebrizaram" (MARIZ, 1983, p. 53). Novamente, Villa-Lobos sofria as contradições de sua época: de um lado, visto como obom selvagem pelos vanguardistas, tais como 
A. Rubinstein, Vera Janacopulos (cantora e sua grande incentivadora), e, de outro, visto como o inimigo da Arte Culta do passado...

A crise financeira deflagrada na Europa em decorrência do crack da Bolsa de Nova Iorque, em 1929; as lutas políticas e os inícios do movimento revolucionário de 30 no Brasil afetaram e tornaram insustentável a permanência de Villa-Lobos em Paris. Devido às bruscas oscilaçōes cambiais, a sua pensāo foi suspensa, levando-o a penhorar e a leiloar todos os seus bens, incluindo partituras e manuscritos.

\section{Artista oficial: a música como missão (São Pau- lo, Botucatu, Rio de Janeiro - 1930-45)}

Convidado pela mecenas Olívia Guedes Penteado, Villa-Lobos retornou a São Paulo em julho de 1930, para reger oito concertos promovidos pela Sociedade Sinfônica de São Paulo. O bom selvagem parisiense foi recebido pelos críticos modernistas como um "regente experiente", graças ao seu trabatho desenvolvido frente às "melhores orquestras européias" (ANDRADE, 1963, p. 145).

Em sua temporada paulistana, Villa-Lobos incluiu nos programas dos concertos, obras de compositores estrangeiros clássico-românticos e simbolistas-nacionalistas contemporâneos, tais como: Concerto Brandemburguês $\mathrm{n}^{\prime \prime} 1$, de Johann Sebastian Bach; VII Sinfonia, de Ludwig von Beethoven; Saudades do Brasil, de Darius Milhaud, e algumas peças de sua autoria: Danças Africanas; Choros $\mathrm{n}^{\text {" }}$ $8 \mathrm{e} \mathrm{10;} \mathrm{Amazonas.} \mathrm{Durante} \mathrm{os} \mathrm{ensaios} \mathrm{e} \mathrm{algumas}$ apresentações desses concertos, ocorreu uma série de atritos pessoais entre o Maestro e os músicos dessa orquestra. De acordo com Mário de Andrade, em suas críticas publicadas na imprensa de 15 de julho a 2 de dezembro de 1930, essas brigas foram desencadeadas, de um lado, em função da "falta de educaçāo" e da "péssima" formaçāo artística de alguns professores da orquestra; e, de outro, em fun- ção da "originalidade" e do excepcional "temperamento" do Regente, não devidamente compreendidos pelos músicos, e o estudo pouco analítico e um tanto "apressado" das partituras por Villa-Lobos, que havia aceito esse convite num momento muito difícil de sua carreira. Para Mário, o resultado da temporada, sob as perspectivas sociais e estéticas, "... foi um conjunto desnorteante de belezas, águasmornas, valores e prejuízos (...). No geral as execuções foram insatisfatórias (...) Faltam a Villa-Lobos várias qualidades que se tornam imprescindíveis a um regente. A sua própria vida angustiosa e variada não the permite se dedicar ao estudo minucioso das partituras (...) Mas se confesso com franqueza estas coisas, estou longe de afirmar que Villa-Lobos esteja impossibilitado de reger. Pode reger perfeitamente, e mesmo, pela originalidade excepcional do seu temperamento pode nos dar às vezes interpretaçōes interessantíssimas. E nos deu várias. Porém para que possa reger com eficácia, um artista nestas circunstâncias tem de contar, antes de mais nada, com a dedicação dos músicos da orquestra. E com esta Villa-Lobos conta na Europa, porque lá o respeitam e as apariçōes dele como regente são episódicas. Mas aqui, terra desabusada, ninguém respeita ninguém. $E$, força é confessar, o conhecimento de que a regência de Villa-Lobos não era episódica, mas duraria por oito concertos, desculpa em grande parte a má-vontade dos músicos" (ANDRADE, 1963, p. 62-63).

Os atritos pessoais travados entre Villa-Lobos e os músicos ocorreram, explícita ou implicitamente, através de ações praticadas pelos artistas, durante essa temporada, tais como: o violino espala chegou a derrubar o arco durante a execução de uma peça; um músico da orquestra se gabou, por ter executado em surdina o Hino Nacional Brasileiro sem que o regente o percebesse; num outro momento, os músicos recusaram-se a tocar peças detcrminadas pelo regente. Para Mário, era possível perceber nos concertos públicos "... olharezinhos que muitos desses 
professores trocavam a cada erro ou vacilação; alguns chegaram a rir francamente!" (ANDRADE, 1963, p. 163). Essas "intrigas", conforme Mário de Andrade, originaram-se, de um lado, pela "indisciplina" e "incompetência" de alguns músicos, $e$, de outro, pela "falta de dedicação" do regente, censurando Villa-Lobos por ter aceito esse convite de Olívia Guedes Penteado num momento em que se encontrava novamente desempregado: “... VillaLobos, nem que morresse de fome, nāo devia se conservar na regência" (ANDRADE, 1963, p. 164).

Esses atritos ou desacatos de colorações aparentemente episódicas, revelam, na realidade histórica, profundas contradiçōes sócio-culturais. $O$ estudo da ciência polf́tica não deve restringir-se somente às análises dos resultados das últimas eleiçōes, por exemplo, mas discutir relaçōes entre pessoas. Os conflitos ocorridos entre Villa-Lobos e os professores da Orquestra da Sociedade Sinfônica de São Paulo denotam um complexo jogo de emoções, açōes, práticas culturais ligadas às representações político-artísticas das elites dominantes brasileiras, durante os anos 20 e 30 .

Esses conflitos denotam, em sua essência, problemas inter-relacionados às seguintes questōes:

$1^{a}$ ) em função da viagem de Villa-Lobos a Paris, considerada pelas elites brasileiras como o símbolo da capital cultural da modernidade, esse compositor, por motivos estético-políticos, passou a exercer a funçāo de regente como uma nova estratégia, a fim de divulgar a sua obra nas capitais curopéias e posteriormente no Brasil, no período pós-30. E, paralelamente, como um novo ofício, capaz de diversificar as suas atividades profissionais. A autoridade $\mathrm{e}$ a competência de Villa-Lobos como regente foi endossada pelos críticos e mecenas brasileiros, a partir de suas peregrinações pela Europa. As novas normas de regência inventadas por Villa-Lobos foram justificadas, por alguns intelectuais modernistas, como índices da exuberância de autor que represen- tava o Brasil Novo, pós-22: "... ora, o que explica Villa-Lobos regente, é justo essa circunstância dele não ser virtuose profissional de orquestra. $O$ que faz nāo sāo tolices, sāo invenções, dados característicos de personalidade. E sempre explicados e defendidos com uma paixảo que só mesmo desse homem, e que vive em família de vesúvios (...) violento, irregular, riquíssimo, quase desnorteante mesmo na varieda. de dos seus acentos, ora selvagem, ora brasileira. mente sentimental, ora infantil e delicadíssimo. Está claro que um temperamento desses não pode dar um cinzelador. De todos os artistas que conheço VillaLobos é o mais incapaz de fazer crochê... "(ANDRA. DE, 1963, p. 147). Porém, a não-formação acadêmica e o autoritarismo do regente chocaram-se com a rígida formação clássica dos músicos da orquestra;

$2^{a}$ ) os músicos formados através de métodos de ensino do violino, flauta, piano, seguiam os cânones da música das alturas (sistema tonal) e, por esse motivo, desconheciam as sutilezas dos novos códigos de linguagem, internalizados porVilla-Lobos nos seus Choros $\mathrm{n}^{\circ} 10$, por exemplo, tornando muito difícil a execução de desenhos rítmicos, altamente complexos;

$3^{a}$ ) parte dos músicos da orquestra e amplas facçōes do público amante de música crudita em São Paulo repudiaram algumas peças de Villa-Lobos, que poderiam eventualmente lembrar o homem sclvagem ou primitivo (índio ou negro, ex-escravo) como a representaçāo política de um Brasil atrasado, colonial ou agrário, num momento de intensa aceleração do processo de urbanização $\mathrm{e}$ de industrialização. $O$ progresso estético-técnico da linguagem villalobiana era visto, de um lado, como o símbolo da vanguarda e da modernidade na música de Darius Milhaud, Mário de Andrade, Vera Janacopulos, Arthur Rubinstein, Sérgio Milliet, Oswald de Andrade, Souza Lima, Arthur Honegger e, de outro, representava para sctores das elites brasileiras, que consumiam música erudita como a metáfora do atraso ou da barbárie. 
Com a falência e dissolução da Sociedade Sinfônica de São Paulo, em 1931, devido à fuga constante de sócios e à frequiente falta de recursos, os intelectuais modernistas começaram a rever as relaఢ̧ões músicos-mecenas; músicos-empresa capitalista + mercado; músicos + apoio oficial do Estado. Para salvar essa orquestra, Mário de Andrade lançou um apelo "angustiado": "... aos que nos governam a cidade e o Estado pra que salvem o que é legitimamente um dos maiores padrões da cultura paulista", e teceu críticas muito ácidas sobre a leviandade dos mecenas brasileiros, em geral, muito "inconstantes" em seus apoios para manter orquestras ou compositores de prestígio como Villa-Lobos: “...Falo 'constante' porque o nosso mecenismo no geral consiste em fazer um gesto brilhante, suponhamos de dez contos, e depois dormir na rede. Isso são ilusões vaidosas, não é proteger nada eficazmente..." (ANDRADE, 1963, p. 243).

E Villa-Lobos enalteceu o apoio do Estado no campo musical, a partir de um outro ponto de vista: o desinteresse, a hostilidade dos músicos eruditos, do público burguês, dos críticos brasileiros, em geral, em face de suas músicas, refletiam uma realidade histórica fundamentada num sistema educacional que renegava o ensino da música como um fator decisivo para a formação de uma consciência nacional: "... de volta de uma das minhas viagens ao Velho Mundo, onde estive em contato com os grandes meios musicais e onde tive a oportunidade de estudar organizaçōes orfeônicas de vários países, volvi o olhar em torno e percebi a desoladora realidade. Senti, com melancolia, que a atmosfera era de indiferença ou de absoluta incompreensão pela música racial, por essa grande música que faz a força das nacionalidades e que representa uma das mais altas aquisições do espírito humano. Percebi que o mal-estar dos intelectuais $\mathrm{e}$ dos artistas não era apenas de um desequilíbrio político e social - mas se originava, em grande parte, de uma crescente materialidade das multidōes, desinteressadas de qualquer espécie de cultura e divorciadas da grande e verdadeira arte musical" (VILLA-LOBOS, 1940, p. 17).

Na residência de Olívia Guedes Penteado, nos Campos Elíseos, Villa-Lobos apresentou um esboço do seu plano de educação musical para Júlio Prestes, Presidente do Estado de São Paulo e candidato à Presidência da República, que lhe prometeu todo apoio, caso fosse eleito. Com a ascensão política de Getúlio Vargas, em outubro, Villa-Lobos pensou retornar para a Europa. Entretanto, o seu projeto despertou um forte interesse nos revolucionários de 30. O interventor de São Paulo - João Alfredo de Lins e Barros (pianista e de razoável sensibilidade artístico-cultural) - entusiasmado pelos ideais cívico-artísticos desse plano educacional, convidou Villa-Lobos para realizar uma tournée pelo interior dos Estados de São Paulo, Minas Gerais e Paraná, num total de 54 concertos.

Nas cidades visitadas, Villa-Lobos ora proferia conferências, denunciando, por exemplo, a preferência do povo pelo futebol: " $\ldots$ o futebol faz desviar a inteligência humana da cabeça para os pés..." (VILLA-LOBOS, H., 1940), ora regia grupos corais ou concertos de música de câmara, ora como intérprete tocava, no violoncelo, algumas de suas obras. Nessas exortaçōes cívico-culturais, Villa-Lobos visava a atingir e envolver novos públicos, ainda virgens em suas escutas em torno do imaginário modernista-nacionalista.

Nos anos 10, o intelectual-artista descobriu o povo em suas andanças pelo Brasil. Em 1931, o artista-oficial e missionário, um apaixonado defensor de uma nova religiâo, de matizes nacional-populistas, voltava a peregrinar pelo interior de Sāo Paulo, ensinando brasilidade para o povo.

Villa-Lobos percebeu, cristalinamente, que os ideais de patriotismo, disciplina, trabalho, progresso, deviam ser impostos para todos os brasileiros 
pelas elites ilustradas, através de um amplo movimento artístico, capaz de canalizar as insatisfações populares afloradas nos fins dos anos $20 \mathrm{e}$ início dos 30: "... dar concertos nas capitais e cidades do interior num momento em que todas as crises - social, econômica, política e até mesmo artística - chegam ao extremo (...) além de semear o gosto da música pura, pela verdadeira arte, senāo elevadas intenções cívicas e patrióticas (...) para elevar o Brasil no conceito das grandes naçōes, e talvez quem sabe para despertar o triste letargo de uma raça sonâmbula" (TEIXEIRA, 1956, p. 87).

Antes de cada espetáculo, Villa-Lobos distribuía panfletos com alguns dados informativos sobre o concerto e considerações sobre a importância do nacional na música, visando a decretar futuramente a independência cultural do Brasil face aos principais pólos culturais estrangeiros. Nesta ocasiāo, o compositor havia se conscientizado da importância da propaganda, como uma arma altamente eficaz para divulgar a nova arte... Em Botucatu, por exemplo, distribuiu o seguinte panfleto para promover o seu concerto: "... Soldados do Brasil, mocidade estudantina botucatuensc, homens do trabalho, juventude brasileira, indústria, comércio, lavoura. Avante! (...) cantemos os nossos hinos clevados e as cançōes sublimes, numa exortação de civismo, de fraternidade c de confiança no futuro do nosso Brasil! (...) Caberá a Botucatu, a capital do sertão, dar uma prova insofismável c vibrante, $o$ iniciador do espírito de cooperação dos brasileiros através da sublime arte musical: Heitor Villa-Lobos - artista genial que, no momento presente, e com a colaboração valiosa de Nair Duarte Nunes, Lucília Villa-Lobos, Anita Gonçalves e Joāo de Souza Lima, aqui chegará, no dia 15 de agosto próximo. A fim de que a briosa população de Botucatu dê uma completa demonstração de seu civismo, tomando parte de todas as manifestaçōes de brasilidade que terão lugar no dia da chegada de Heitor
Villa-Lobos, cantando os hinos Pr'a Frente, $\delta$ Brasil!; Meu País e Brasil Novo..." 13

Com a revoluçāo de 30 , tornou-se possível divulgar, através do apoio do Estado, o imaginário musical modernista entre amplas facçōes das elites dominantes e outras fraçōes de classes, "... esse momento onde o excepcional se torna usual, tendendo o que era restrito a se ampliar. O decênio de 1930, viu com efeito o alargamento das práticas literárias e artísticas, transformando aos poucos em padrão de uma época o que era considerado manifestaçāo de pequenos grupos vanguardeiros (...) Na literatura, o que parecia brincadcira foi sendo reconhecido como normas dos tempos novos, até penetrar no jardim fechado e vigiado do ensino... era a revolução entrando na rotina" (CANDIDO, 1971, p. XIV).

O sucesso dessa tournée de Villa-Lobos, patrocinada pelo governo de São Paulo pós-outubro, 1930, inter-relacionou-se com o amplo movimento cívico que atingiu segmentos dominantes e dominados da sociedade brasileira. $\mathrm{Na}$ realidade, o esboço de projeto de Villa-Lobos, inspirado nos modelos alemães e franceses da época, graças à ampla receptividade do público e da imprensa paulista e paulistana, aflorou como algo viável, tornando-se o cmbriāo de uma metodologia, posteriormente desenvolvida e aprofundada na cidade do Rio de Janciro, sobre o ensino do canto orfeônico nas escolas primária e secundária.

Nos anos 20, muitos educadores, críticos, compositores, começaram a defender, isoladamente, o ensino do canto orfeônico como um ideal de coesão social. Em 1928, Mário de Andrade, no Diário Nacional, chamava a atenção da opinião puiblica para

13. Documento avulso. Álbum de recorres, organizado por Arminda Villa-Lobos. Arquivo Museu Villa-Lobos, Rio de Janeiro. 
esta questão: "... com a festa linda de ontem no $\mathrm{Mu}$ nicipal de São Paulo, o Orfeão Piracicabano veio dar a S. Paulo uma lição artística de civismo (...) o mundo brasileiro é tão dissociado, o indivíduo brasileiro tão isolado..."14

O projeto villalobiano de educaçāo musical harmonizou-se com o debate em torno da função social da música em voga nos fins dos anos 20 : “... o critério atual da Música Brasileira deve ser não filosófico, mas social. Deve ser um critério de combate..." (ANDRADE, 1962, p. 19).

Os ideais patrióticos e cívicos já haviam se manifestado $\mathrm{em}$ alguns hinos e cançōes escritos por Villa-Lobos em momentos anteriorcs à Semana de 22. Em 1919, compôs o hino Meu País e a Canção dos artistas. Em 1922, o hino Brasil Novo. Em 1925 6, harmonizou dois cantos folclóricos: Cantiga de roda e Na Bahia tem. Excetuando-se Meu País, hino executado uma única vez, em 1926, os outros textos de matizes cívico-ufanistas foram praticamente ignorados durante a década de 20 . Somente com a revolução de 30 , Villa-Lobos encontrou um clima favorável para divulgar esse tipo de repertorio. Nesta ocasião, escreveu P'ra Frente, ó Brasill, que alcançou um retumbante sucesso de público e de crítica. Para Villa-Lobos, 1930 significou uma virulenta ruptura com o passado histórico: “... a revolução, trazendo à tona tudo o que necessita remodelaçāo urgente, não deixará, estou certo, de considerar os aspectos de educação artística do brasileiro, pois, não negará, também, que esses 40 milhōcs de homens que formam a nação, e que aspiravam à liberdade $e$ ao uso de direitos políticos estão habilitados a ter a 'sua' arte (...) desde a Grécia antiga até a Alemanha, a França, a Rússia de hoje e outros países, a arte tem

14. Diário Nacional. São Paulo, 15 julho 1928. sido a luz que ilumina e põe em relevo a obra de progresso dos povos..." ${ }^{15}$ Conscientizando-se sobre a importância do Estado para exercer o papel de mecenas, Villa-Lobos, Lorenzo Fernandez, Bidu Sayão, Mário de Andrade, Luciano Gallet, enviaram para os burocratas recém-empossados no poder por Getúlio Vargas, projetos, cartas, solicitando medidas severas e urgentes do novo governo, no sentido de criar condiçōes para apoiar e desenvolver a arte nacional.

Para Villa-Lobos, as palavras-chave como clássico, romântico, popular, folclórico, somente poderiam ser empregadas pelo artista profissional e não pelo público infantil ou adolescente, que deveria aprender a reconhecer todos os tipos de sons para apreciá-los. Assim, o ideal de beleza deveria ser definido pelo hábito e pela educação: "... habitue-se o ouvido de nossa juventude ao que, segundo a nossa herança acumulava, ć belo, e o seu gosto será são" 16

No seu texto sobre a Educaf̧ão Musical, Villalobos classificou os compositores em três categorias: "... os que escrevem música-papel, segundo regras ou modas; os que escrevem para ser 'originais' e realizar algo que os outros não realizaram, e, finalmente, os que escrevem música porque não podem viver sem ela. Só a terceira categoria tem valor" "7. Nesta última categoria, o artista deveria cultivar e estudar as heranças e tradições musicais, literárias, políticas para internalizar a "verdadeira alma do povo" ou a "alma folclórica".

Para atingir os seus objetivos educacionais, VillaLobos defendia uma reforma radical do ensino, a ser

15. O Jornal. Rio de Janeiro, 8 nov. 1930.

16. Manuscrito n"74-18A-2E. Rio de Janeiro, Livro do Tornbo, Museu Villa-Lobos.

17. Idem. 
promovida pelo governo de Getúlio Vargas em prol da formação cívica e humanística dos compositores, em particular, e do povo, em geral.

Em 1931, sob o patrocínio oficial do governo do Estado de São Paulo e do diretor de instrução pública - Lourenço Filho -, Villa-Lobos apresentou-se nos estádios de futebol da capital paulista, "... realizando em São Paulo a primeira iniciativa do canto coletivo, em grande conjunto, e na América do Sul" (VILLA-LOBOS, 1937, p. 11). Para chamar a atenção das pessoas, a fim de comparecerem nesses espetáculos cívico-artísticos, o compositor distribuía panfletos, ora lançados por aviōes, ora entregues nas escolas, fábricas, academias, ora divulgados através da imprensa escrita. E, paulatinamente, foi-se aproximando de novos públicos consumidores de suas músicas e de suas propostas político-culturais.

A partir desse momento, Villa-Lobos passou a defender, ardorosa e apaixonadamente, a oficialização do ensino do canto orfeônico nas escolas, como a única arma capaz de combater e extinguir todos os males ou entraves que pudessem ameaçar o projeto modernista em prol da nacionalização da música, como a "... ausência de patriotismo dos artistas, empresários, e do público, em geral, consumidores de música estrangeira de 'má qualidade' ou de músicas popularescas estrangeiras ou brasileiras, como as sertanejas, veiculadas pela indústria do entretenimento (rádio, cinema, disco)" 18 .

18. “... assinalava-se tamberm uma aproximação entre as formas de teatro já consagradas (revistas, operetas, burletas), com os gêneros e celebrações populares, mormente as do Rio, mas já fazendo representar igualmente os sentimentos regionais (os sertanejos, 'gêneros do norte', 'folclore'.). Não poderia, então, faltar o carnaval, trazendo ao palco os folióes das grandes sociedades, com suas marchinhas, como a reforçar um papel que ganha mais e mais a expressão de vestibular da celebraçăo, delimitando as temáticas segundo um critério sazonal, preparando o desen-
Em 18 de abril de 1931, através do Decrerto n ${ }^{\circ}$ 19.980, foi instituído no país o ensino obrigatório do Canto Orfeônico nas escolas da cidade do Rio de Janeiro. Em 1932, Villa-Lobos foi nomeado para exercer o cargo de Diretor da Superintendência de Educação Musical e Artística das Escolas Públicas do Rio de Janeiro (SEMA). Durante os anos 30. Villa-Lobos ora escrevia músicas, ora abordava questōes teórico-metodológicas sobre o ensino do Canto Orfeônico; ora criava concertos educacionais, ora regia massas corais para comemorar o Dia de Santa Cecília ou o Dia da Pátria.

Sob o governo getulista (1930-45), Villa-Lobos consolidou um amplo projeto em prol da catequese do povo brasileiro através de atividades artísticas. Por exemplo, a execução do hino P'ra Frente, ó Brasil! deveria obedecer ao ritmo de tambor militar a ser executado obstinadamente durante toda a marcha; "... como um toque de alvorada, o advento da música nacionalista veio despertar as energias raciais adormecidas. Como um toque de clarim na madrugada clara de uma vida nova, os hinos $\mathrm{e}$ as canções patrióticas aprendidas com alegria nas escolas, espalharam-se festivamente pelos céus do Brasil. E os seus ccos longínquos acordaram o homem incré-

volvimento da 'chanchada' no palco (...) A tendência que desde 1922 já operava no sentido de valorizar a cançđo popular, se reforçou depois de 1930, amparada pela fixaçāo da canção urbana do Rio, por sua vez beneficiada pela consolidação da indústria fonográfica e pela recente introdução do rádio (...) De fato, as operetas c filmes musicais faziam grande sucesso desde 1929. com a chegada ao Brasil do cinema sonoro, produzindo, por efeito, uma grande variedade de burletas e operetas, farsas musicadas, gêneros quase indistintos." BARROS, Orlando de. Custódio Mesquita, um compositor romântico. O entretenimento, a canção sentimental e a política no tempo de Vargas (1930-45). Tese de Doutoramento. São Paulo, FFLCH-USP, 1995, (I):174-6. 
dulo, levando-lhe ao coração palavras de $f e$, serenidade e energia. - P'ra frente, 6 Brasil!" (VILLALOBOS, 1940, p. 59-60).

Nos programas de música erudita idealizados por Villa-Lobos nos Concertos para a Juventude no cinema Rex, ou para os operários no Teatro João Caetano, foram incluídos clássicos da literatura musical: - A Missa do Papa Marcelo de Palestrina; A Grande Missa Solene de $\mathrm{L}$. von Beethoven ou as suas peças eruditas, como o oratório Vidapura - almejando incutir no povo o gosto pela arte culta universal, etapa imprescindível na busca do progresso e da civilizaçäo. Muitos críticos, professores, artistas, imbuídos dos ideais da tradição da Belle Époque, criticaram Villa-Lobos, como a encarnação do artista oficial da ditadura varguista (em especial, pos-37), preocupado com a sua autopromoção e com a distribuição de verbas oficiais para os seus amigos.

Os primeiros cursos ministrados por Villa-Lobos eram, fundamentalmente, baseados no empirismo e em algumas técnicas inspiradas nos manuais de ensino escritos pelos pedagogos franceses dos anos 20 . Nesta fase, era imprescindível formar, num curto período de tempo, novos professores para atender à nova estrutura da grade curricular, implantada pelos idé́logos da Escola Nova. Para Villa-Lobos, a concretizaçāo do seu projeto deveu-se ao irrestrito apoio das autoridades do governo getulista: "... a nova idéia venceu todas as resistências e se impôs como uma necessidade imprescindível, não sర à educaçāo como até à própria vida espiritual da infância brasjleira. Esse milagre só poderia ser realizado dentro das normas de um Governo Forte e perfeitamente esclarecido dos problemas sociais e educativos do seu povo" (VILLA-LOBOS, H., 1940, p. 67).

Em 10 de maio de 1932, foi criado o Orfeão dos Professores do Distrito Federal pela Direção Geral da Instrução Pública, formado pelos alunos dos cursos de Pedagogia, pelos professores subordinados à SEMA e pelos professores da Orquestra do Teatro
Municipal. Esse conjunto coral era constituído de 250 pessoas e, em poucos meses de ensaio, VillaLobos regeu-o no Teatro João Caetano. No intervalo desse concerto ( 7 de setembro), Villa-Lobos distribuiu um texto-manifesto, no qual enfatizava a arte musical como um importante veículo de propaganda do regime político: "...Avante brasileiros! Todos os povos fortes sabem cantar em coro. Nas horas tristes e nos momentos felizes (...) Só a educação resolverá os problemas brasileiros..." 19.

Os concertos programados nos Teatros Municipal e Joảo Caetano eram, em geral, gratuitos, visando a seduzir um público oriundo das camadas mais humildes da população. Os convites eram distriburdos nas portas das fábricas, das escolas... "Operários!!! Descansem o corpo! Alimentem em poucos minutos o seu espírito, a sua alma, no domingo de música dos operários, dia 28 de abril próximo, às 17 horas. Cinqüenta minutos de sensações artísticas! No Teatro João Caetano não haverá bilhetes, nem porteiros. As portas estarão abertas, de lado a lado, como vivo na sua intimidade o silêncio será mantido pela propria emoção. Trabalhadores, venham assistir, ao menos como experiência, o que o Orfeão de Professores do Distrito Federal lhes oferecerá. Até domingo! Heitor Villa-Lobos" 20 .

De acordo com Villa-Lobos, a música era um instrumento de poder, capaz de transformar a mentalidade dos homens. Implicitamente, esse projeto educacional representava, através dos conjuntos corais, uma Nação coesa, sem conflitos sociais. Sob

19. Diário de Nolicias. Rio de Janeiro, set. 1932.

20. Documento avulso. In: Álbum de Recorses, organizado por Amninda Villa-Lobos. Rio de Janeiro, Arquivo do Museu VillaLobos. 
esse prisma, o canto orfeônico era uma arma do getulismo visando a despolitizar amplos segmentos das camadas médias e dominadas da sociedade. O sucesso conjuntural desse projeto, durante o Estado Novo, em especial, atrelou-se a um discurso emotivo, envolvente, romântico, que almejava incutir nos jovens ideais de disciplina e trabalho, considerados fundamentais na construção de uma sociedade civilizada.

A apresentação de grandes conjuntos corais, que variavam entre 250 a 60.000 pessoas, simbolizava um grande espelho da própria sociedade. Nesses programas, eram incluídas canções que representavam o universo corporativista do getulismo: de um lado, cantores oriundos do Corpo de Bombeiros, das escolas primárias e secundárias, da Polícia; das Associaçōes de escoteiros ou do operariado; e, de outro, canções que exaltavam os ofícios de marceneiro, ferreiro, aviador ou os heróis da Pátria do passado (Tiradentes, Santos Dumont) ou do presente (Getúlio Vargas, Capanema) ou, ainda, as belezas naturais da Nação: florestas, rios, pássaros...

Graças a um matiz do liberalismo econômico do governo getulista, a música estrangeira popular, ligeira, erudita, invadia todos os lugares das memórias da cidade do Rio de Janeiro: grandes cinemas que exibiam os musicais da RKO, com Fred Astaire e Ginger Rogers, ou da Metro (Jeannette Mc Donald, Nelson Eddy); emissoras de rádio (músicas de Cole Porter, Benny Goodmann, Glenn Miller); dancings, cassinos; Teatro Municipal (6peras). Versões de canções americanas, francesas, italianas, eram entoadas pelos artistas brasileiros - Francisco Alves, Orlando Dias.

O projeto nacionalista de Villa-Lobos, durante os anos 30, foi criticado pelas elites que defendiam o caráter não-funcional e totalmente assemântico da música. Por essa razão, continuaram prestigiando as companhias italianas de ópera que visitavam o Rio de Janeiro e São Paulo. E, paralelamente, os empre- sários da indústria do entretenimento voltavam-se para o consumo de música estrangeira pelas camadas médias.

No âmbito desse coro dos contrários, Villa-Lobos criticava e atacava os responsáveis pela divulgação da música estrangeira, através do seu amplo projeto educacional. Em muitas ocasiōes, Villa-Lobos criticou a açảo governamental que apoiava, implicitamente, essa entrada maciça de música estrangeira, capaz de corromper o público e implodir o seu projeto... Em 1939, Gustavo Capanema, ministro da Educaçāo e Saúde, demonstrou uma certa preocupação em face da entrada de músicas estrangeiras através do cinema, das partituras, do disco. E, por essa razão, solicitou a Villa-Lobos a redação de um novo projeto, capaz de combater essa invasão.

Em resposta à solicitação de Capanema, VillaLobos elaborou um programa visando a consolidar a hegemonia do nacional e do popular na música, fixando o seu "característico fisionômico" como "... a Espanha, a Alemanha, a Rússia, a Itália, os Estados Unidos da América do Norte e outros que já se impuseram no mundo, dominando as tendências dos países mais fracos, ou povos indiferentes..." $"$

Capanema e Villa-Lobos, nos inícios dos anos 40 , uniram-se em torno de uma luta em prol do estabelecimento de uma política cultural mais homogênea, mais rigorosa sobre a música brasileira, a ser controlada, fiscalizada com rigidez pelos órgãos de censura do Estado, abrangendo o ensino, a difusāo da música vocal e instrumental, a pesquisa do folclore.

Em 1941, Villa-Lobos demonstrou a sua profunda irritação em face do aceleramento da invasão norte-americana no Brasil, solicitando do governo

21. Manuscrito. Arquivo Gustavo Capanema. Rio de Janeiro, CPDOC-FGV, GC/f 37.00.00/4. 
a tomada de medidas urgentes para criar um Departamento Nacional de Música e de Teatro, como a única barreira capaz de salvar "... a Arte de nossa querida Pátria!" 22.

Com a aliança Roosevelt/Getúlio, a presença cultural norte-americana, em geral, e de outros países, em particular, tornou-se uma realidade histórica irreversível... Em 1945, Villa-Lobos, profundamente magoado com o governo, que não havia implementado nenhuma de suas sugestōes anteriores face à americanização da cultura brasileira, redigiu o novo projeto, que preconizava a construção de um Teatro Nacional de Ópera; a criação de uma Orquestra Sinfônica Nacional, entre outras medidas concretas para inserir a música brasileira "... nos fóros do progresso e da civilização...". Algumas semanas depois, deu-se a queda de Getúlio e do Estado Novo...

\section{4. $O$ compositor nacionalista e a indústria do en- tretenimento (New York, Los Angeles, Paris) (1944-59)}

Na qualidade de organizador do sistema educacional na área musical durante o governo Vargas, Villa-Lobos fixou residência na cidade do Rio de Janeiro no período de 1931 a 45, viajando para o exterior esporadicamente, para divulgar o seu projeto nacionalista: Teatro Colón (Buenos Aires, maio 1935); Praga (1936); Montevidéu (1940), tournée pelos Estados Unidos (novembro de 1944); Nova Iorque (Carnegie Hall, 13 março 1945).

No Brasil, Villa-Lobos lutava pela concretizaçāo do seu projeto sobre a nacionalizaçāo da música através de uma série de práticas político-culturais e ad-

22. Idem. ministrativas. Nas suas viagens ao exterior, VillaLobos tornava-se o símbolo do perfil sonoro da Nação. As suas obras eram veiculadas como os símbolos da grandeza, da riqueza, da pujança, da cultura e da raça brasileiras. E, paralelamente, as suas ousadias no campo da linguagem musical agradavam os artistas (compositores, intérpretes, maestros) que comungavam os mesmos ideais técnico-estéticos: Leopold Stokowsky, Aaron Copland, Cole Porter, Arturo Toscanini, Benny Goodman, Claudio Arrau.

A partir de 1945, Villa-Lobos, ainda prestigiado no Brasil como o porta-voz da cultura nacionalista, procurou direcionar sua carreira em busca de novos públicos. Contratado, em outubro de 1946, para reger dois concertos no Teatro Colón de Buenos Aires, Villa-Lobos selecionou a Segunda Sinfonia, o Choro $\mathrm{n}^{\circ} 12$, a Bachiana $\mathrm{n}^{\circ} 7$, a primeira e a segunda suítes do Descobrimento do Brasil e os Choros $n^{\circ} 10$. Nos inícios de 1947, Villa-Lobos empreendeu a sua segunda tournée pelos Estados Unidos para escrever, sob encomenda de Robert Wright e George Forrest, a opereta Magdalena, conforme cânones da indústria do entretenimento da Broadway, calcada nos grandes sucessos, como Show Boat (Jerome Kern e Oscar Hammerstein II) ou Porgy and Bess (G. Gershwin). A complexidade temática proposta por Wright e Forrest - artistas com longa experiência nos estúdios de Hollywood e nos musicais da Broadway - exigia uma narrativa musical capaz de abranger o matiz da simplicidade religiosa de uma Bachiana à complexidade rítmica do $4^{\circ}$ movimento das Bachianas $n^{\circ} 2$ (O Trenzinho Caipira), ou ainda, a singeleza de uma canção folclórica ou a grandiloquiência de um hino patriótico (frenético), ou ainda, os ritmos de uma valsa parisiense ou de um batuque bravo oriundo das culturas dos negros brasileiros.

A opereta Magdalena, uma aventura musical estreou em Los Angeles em 26 de julho de 1948. Foi produzida por Erwin Lester e dirigida por Jules Dassin, tendo recebido excelentes críticas publicadas 
nos jornais locais. Em Nova Iorque foi encenada no Teatro Ziegfeld, numa brevíssima temporada, devi. do à greve deflagrada pelo Sindicato dos Músicos, que paralisou emissoras de rádio e teatros nos Estados Unidos durante alguns meses.

Após ter sido hospitalizado no Memorial Center, empreendeu diversas tournées pelas principais cidades da Europa e das Américas, ora atendendo a solicitações oficiais para escrever obras sob encomenda (compôs, por exemplo, a Décima Sinfonia ou Sume pater patrium para as comemorações do IV Centenário da Cidade de São Paulo, em 1954), ora atendendo a convites de Sociedades de Estudos Folclóricos para proferir conferências, ora atendendo a convites formulados por empresários. O ritmo frenético de suas viagens - de Tel-Aviv a Los Angeles - prende-se à sua concepção da música como um outro tipo de religião. E, na qualidade de um peregrino-missionário, almejava divulgar entre os "povos do mundo", a sua música como a representação da "alma e do retrato sonoro do Brasill" Numa entrevista, Villa-Lobos relata, com paixão, um itinerário a ser concretizado num breve espaço de tempo: “... De Londres devo ir a Paris, talvez para reger em primeiro lugar a Orquestra da Radiodifusão e possivelmente uma das outras grandes orquestras que ainda não sei qual será. Depois irei a Roma, onde tenho dois concertos (...) Sobre outros concertos $\mathrm{em}$ Viena, Bruxelas, Genebra, Praga e Lisboa, ainda não tenho datas marcadas. Além dos concertos, tenho várias conferências, como por exemplo uma a 21 deste mês, na Sorbonne, sob a iniciativa de diversas instituiçōes folclóricas da França. Ainda terei uma viagem aos Estados Unidos, que está dependendo de algumas circunstâncias e que será, além de concertos, assistir à première de minha opera Magdalena, a ser levada em meados deste ano, em Los Angeles..." (Apud MACHADO, 1987, p. 117).

Durante as décadas de 30 e 40, o discurso nacionalista, sob matizes diversos, tornou-se oleitmotiv dominante dos programas de governo de Roosevelt, Trumann, Getúlio Vargas, E. G. Dutra, J. Perón, Franco, Hitler, Salazar, Mussolini, Stalin. Na música erudita, o nacional e o popular transfiguraramse numa ampla tendência estética, aceita por vastos segmentos sociais. Traços simbolistas, primitivos (influências do jazz, dos choros, por exemplo), internalizaram-se nas obras dos mais significativos compositores ligados à Arte Culta ou à indústria do entretenimento, tais como: Irving Berlin, George Gershwin, Cole Porter, Manuel De Falla, Villa-Lobos, Igor Strawinsky, Edgard Varèse. Por essa razão, os "públicos" de Villa-Lobos ampliaram-se significativamente nos principais pólos culturais europeus e americanos.

Irônica ou tragicamente, os Donos do Poder, durante a "era Vargas", nunca accitaram os projetos de Villa-Lobos a respeito da construção de grandes teatros de ópera nas principais cidades brasileiras ou a criação de orquestras sinfônicas ou corpos de baile mantidos por verbas oficiais. Somente incentivaram o ensino do canto orfeônico nas escolas... Nunca foram construídos no Brasil teatros como o Radio City Music Hall, sob o patrocínio do Estado ou pela iniciativa privada, para divulgar as obras de VillaLobos, o selvagem da sociedade civilizada e progressista, consoante os discursos político-culturais das elites brasileiras...

\section{Bibliografia}


ARAÚJo, Rosa Maria Barboza de. A Vocaçắo do Pruzer. A Cidade e a Famflia no Rio de Janeiro Republicano. Rio de Janeiro, Rocco, 1993.

CANDIDO, Antonio. "Prefácio". In: DUARTE, Paulo. Mário de Andrade por ele mesmo. Săo Paulo, 1971.

ELIAS, Norbert. Mozart, Sociologia de um Gênio. Rio de Janeiro, Jorge Zahar, 1995.

FIREDRICH, Otto. Olympia. Paris no tempo dos impressionistas. São Paulo, Companhia das Letras, 1993.

HORTA, Luiz Paulo. Villa-Lobos. Uma introduçäor. Rio de Janeiro, Jorge Zahar, 1987.
MACHADO, Maria Célia. Heitor Villa-Lobus. Tradiçăo e Renovação na Másica Brasileira. Rio de Janciro, FranciscoAlves/ UFRJ, 1979.

TEIXEIRA, Anísio. A Educaçăo e Crise Brasileira. São Paulo, Companhia Editora Nacional, 1956.

VILLA-LOBOS, Heitor. A Música Nacionalista no Govêrno Vargas. Rio de Janeiro, DIP, 1940.

WAGNER, Richard. A Arte e a Revoluçäo. 1849. Lisboa, Antígona, 1990.

WISNiK, José Miguel. O Som e o Sentido. Uma outra Histớria das Músicas. São Paulo, Companhia das Letras, 1989.

Endereço do Autor: Rua Caraibas, I199, apl 71 -A - CEP 05020-000 - São Paulo • SP • Brasil 